\title{
Multi-Amplified Sensing of MicroRNA by a Small DNA Fragment-Driven Enzymatic Cascade Reaction
}

\author{
Eunjung Kim, Philip D. Howes, Spencer W. Crowder, and Molly M. Stevens* \\ Department of Materials, Department of Bioengineering and Institute for Biomedical Engineering, Imperial \\ College London, London, SW7 2AZ, United Kingdom \\ E-mail: m.stevens@imperial.ac.uk
}

\section{Table of Contents}

\section{EXPERIMENTAL SECTION}

Determination of melting temperature $\left(\mathrm{T}_{\mathrm{m}}\right)$

Determination of the number of A10 DNA on the surface of MPs …..............................................

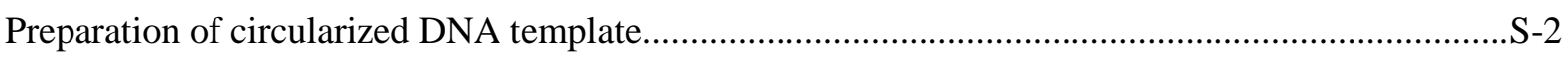

Determination of the amplification factor of $\mathrm{T}_{\mathrm{c}}$ fragments-mediated RCA ...................................... $\mathrm{S}-2$

Detection of target miRNA spiked into human serum.........................................................................

\section{SUPPLEMENTARY TABLE AND FIGURES}

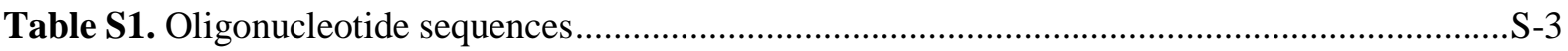

Figure S1. Temperature-dependent catalytic activity of DSN ….................................................

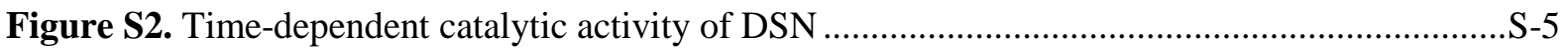

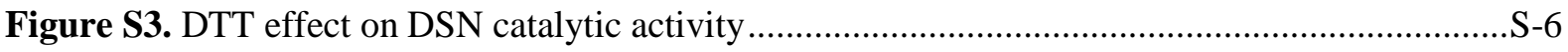

Figure S4. The effect of $\mathrm{MgCl}_{2}$ concentrations on DSN catalytic activity .........................................

Figure S5. The effect of reaction temperatures on DSN catalytic activity ..........................................

Figure S6. Melt curve analysis of DNA/miRNA duplexes ………...............................................

Figure S7. DSN catalytic activity on $1 \mathrm{nt}$ mismatched DNA in DNA/miRNA heteroduplexes .........S-8

Figure S8. PAGE analysis showing circularization of template DNA …..........................................

Figure S9. 8\% native PAGE analysis of the RCA products in the presence of DSN .........................

Figure S10. Melt curve analysis of $T_{c}$ hybridization with template DNA in RCA reaction buffer ....S-9

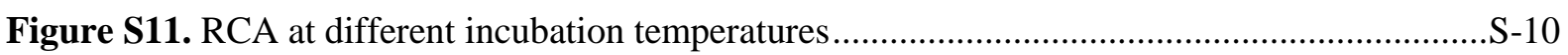

Figure S12. Comparison of detection limit between $\mathrm{T}_{\mathrm{c}^{-}}$and $\mathrm{T}_{\mathrm{c}, \mathrm{syn}}$-mediated RCA …...................... $\mathrm{S}-10$

Figure S13. Detection of target miRNA (miR-21) spiked in 20\% human serum ............................S-11

Figure S14. Quantification of miR-21 with qRT-PCR .............................................................

Figure S15. Quantification of miR-21 with $\mathrm{T}_{\mathrm{c}}$-primed RCA …................................................... $\mathrm{S}-12$ 


\section{EXPERIMENTAL SECTION}

\section{Determination of melting temperature $\left(\mathbf{T}_{\mathrm{m}}\right)$}

For melting curve analysis, each A10 DNA/miRNA duplex $(1 \mu \mathrm{M}, 18 \mu \mathrm{L})$ prepared in DSN reaction buffer ( $50 \mathrm{mM}$ Tris-HCl, $1 \mathrm{mM}$ DTT, $\mathrm{pH}$ 8.0) with various $\mathrm{MgCl}_{2}$ concentrations was mixed with 2 $\mu \mathrm{L}$ of $20 \times$ SYBR green I, and the fluorescence intensity was monitored on the StepOnePlus RealTime PCR system (Applied Biosystems, USA). The temperature rose from $30{ }^{\circ} \mathrm{C}$ to $95{ }^{\circ} \mathrm{C}$ at a rate of $0.3^{\circ} \mathrm{C} / \mathrm{sec}$.

For measurement of $\mathrm{T}_{\mathrm{m}}$ between $\mathrm{T}_{\mathrm{c}}$ and linear or circular template DNA, the mixtures $(20 \mu \mathrm{L})$ of each template DNA $(1 \mu \mathrm{M}), \mathrm{T}_{\mathrm{c}, \mathrm{syn}}(1 \mu \mathrm{M})$, and $2 \times \mathrm{SYBR}$ green I were prepared in the RCA reaction buffer (50 mM Tris- $\mathrm{HCl}, 10 \mathrm{mM} \mathrm{MgCl} 2,10 \mathrm{mM}\left(\mathrm{NH}_{4}\right)_{2} \mathrm{SO}_{4}, 4 \mathrm{mM}$ DTT, $\mathrm{pH}$ 7.5). The temperature was increased from $4{ }^{\circ} \mathrm{C}$ to $95{ }^{\circ} \mathrm{C}$ at a rate of $0.3{ }^{\circ} \mathrm{C} / \mathrm{sec}$. The $\mathrm{T}_{\mathrm{m}}$ was obtained by converting the fluorescence data into the negative derivative of fluorescence as a function of temperature.

\section{Determination of the number of A10 DNA on the surface of MPs}

To quantify the amount of A10 DNA bound to MPs, the supernatant was incubated with Oligreen reagent for $5 \mathrm{~min}$ at room temperature, followed by fluorescence intensity measurements using an EnVision multilabel reader (Perkin Elmer, USA) at $\lambda_{\mathrm{ex}}=480 \mathrm{~nm}$ and $\lambda_{\mathrm{em}}=520 \mathrm{~nm}$. For the quantification of Cy5-A10 DNA, the fluorescence intensity of the supernatant was recorded at $\lambda_{\mathrm{ex}}=$ $648 \mathrm{~nm}$ and $\lambda_{\mathrm{em}}=668 \mathrm{~nm}$. The standard curves for each A10 DNA and Cy5-A10 DNA were obtained using the same DNA with known concentrations. The loading amount was calculated by comparison of the concentration of DNA in the supernatant with the initial known concentration. The calculated number of DNA strands per MP was $4.0 \times 10^{5}$ for MPs-A10 DNA and $3.9 \times 10^{5}$ for MPs-Cy5-A10 DNA.

\section{Preparation of circularized DNA template}

For the circular DNA template, $5 \mu \mathrm{L}$ of 5 '-phosphorylated linear DNA template $(100 \mu \mathrm{M})$ was hybridized with $6 \mu \mathrm{L}$ of primer $(100 \mu \mathrm{M})$ in $1 \times \mathrm{T} 4 \mathrm{DNA}$ ligase reaction buffer $(50 \mathrm{mM}$ Tris- $\mathrm{HCl}, 10$ $\mathrm{mM} \mathrm{MgCl} 2,10 \mathrm{mM}$ DTT, $1 \mathrm{mM}$, ATP, pH 7.5) by heating at $80{ }^{\circ} \mathrm{C}$ for $10 \mathrm{~min}$ and subsequent cooling to room temperature for at least $2.5 \mathrm{hr}$. For ligation, $5 \mu \mathrm{L}$ of T4 DNA ligase ( $400 \mathrm{U} / \mu \mathrm{L})$ was then added and incubated at $16{ }^{\circ} \mathrm{C}$ for $16 \mathrm{hr}$. The enzyme was denatured by heating at $65{ }^{\circ} \mathrm{C}$ for 10 min. To digest the remaining ssDNA and dsDNA in the resulting mixture, $5 \mu \mathrm{L}$ of each Exo I (20 $\mathrm{U} / \mu \mathrm{L})$ and Exo III $(100 \mathrm{U} / \mu \mathrm{L})$ was treated and incubated at $37{ }^{\circ} \mathrm{C}$ for $1.5 \mathrm{hr}$. To compare with Exo I/III-treated circularized template DNA, the ligated template DNA was also treated with Exo VII (10 $\mathrm{U} / \mu \mathrm{L}$ ) at $37^{\circ} \mathrm{C}$ for $1 \mathrm{hr}$. The enzymes were inactivated by heating at $80{ }^{\circ} \mathrm{C}$ for $15 \mathrm{~min}$. The ligation and digestion of intended products were confirmed by both 15\% native and denaturing PAGE analysis in $1 \times$ TBE buffer. The circularized DNA template was finally purified using a centrifugal filter device (Amicon, MWCO $10 \mathrm{kDa}$ ) and stored at $-20{ }^{\circ} \mathrm{C}$ until use.

\section{Determination of the amplification factor of $\mathbf{T}_{\mathrm{c}}$ fragments-mediated RCA}

To assess the amplification factors of $\mathrm{T}_{\mathrm{c}}$ fragment-primed RCA, the RCA was carried out using both the amplified $\mathrm{T}_{\mathrm{c}}$ generated from the target miRNA with various concentrations $(200 \mathrm{fM}, 2 \mathrm{pM}, 20 \mathrm{pM}$, and $200 \mathrm{pM})$ and synthetic $\mathrm{T}_{\mathrm{c}}\left(\mathrm{T}_{\mathrm{c}, \mathrm{syn}}\right)$ with $20 \mathrm{nM}, 40 \mathrm{nM}, 60 \mathrm{nM}, 80 \mathrm{nM}$, and $100 \mathrm{nM}$. For comparison, $\mathrm{T}_{\mathrm{c}, \mathrm{syn}}$ solution was prepared by adding $0.25 \mathrm{U}$ of DSN in $1 \times$ DSN reaction buffer, following by heating at $95{ }^{\circ} \mathrm{C}$ for $30 \mathrm{~min}$. The DSN and RCA reactions were performed in the same procedures as described above. The concentration of the amplified $\mathrm{T}_{\mathrm{c}}$ fragments was determined using a calibration curve obtained from the fluorescence signals to the $\mathrm{T}_{\mathrm{c}, \mathrm{syn}}$ concentrations. 


\section{Detection of target miRNA spiked into human serum}

$10 \mu \mathrm{L}$ of freshly thawed human serum was mixed with $5 \mu \mathrm{L}$ of miR-21 with various concentrations. Next, $35 \mu \mathrm{L}$ of MPs-A10 DNA was added to a final concentration of $600 \mathrm{nM}$ and incubated in $1 \times$ DSN reaction buffer at $37{ }^{\circ} \mathrm{C}$ for $15 \mathrm{~min}$ to allow DNA/miRNA hybridization. To remove residual serum, the MPs-A10 DNA/miRNA was washed with $1 \times$ DSN reaction buffer twice and followed by the reaction with $0.25 \mathrm{U}$ of DSN at $55{ }^{\circ} \mathrm{C}$ for $2 \mathrm{hr}$. The $\mathrm{T}_{\mathrm{c}}$ fragments were collected by separating the solution from the particles and heated to $95{ }^{\circ} \mathrm{C}$ for $30 \mathrm{~min}$. After cooling to room temperature, the $\mathrm{RCA}$ reaction and detection of the RCA products were performed in the same way as described above.

\section{SUPPLEMENTARY TABLE AND FIGURES}

Table S1. Oligonucleotide sequences

\begin{tabular}{|l|l|}
\hline Name & Sequence $\left(\mathbf{5}^{\prime} \rightarrow \mathbf{3}\right.$ ') \\
\hline miR-21 probe DNA (A0 DNA) & TCA ACA TCA GTC TGA TAA GCT A \\
\hline miR-21 probe DNA (A10 DNA) & $\begin{array}{l}\text { TCA ACA TCA GTC TGA TAA GCT A- } \\
\text { poly(A) })_{10}\end{array}$ \\
\hline A10 DNA with biotin (A10 DNA biotin) & $\begin{array}{l}\text { TCA ACA TCA GTC TGA TAA GCT A- } \\
\text { poly(A) })_{10} / 3 \text { biotin/ }\end{array}$ \\
\hline $\begin{array}{l}\text { A10 DNA with biotin and Cy5 } \\
(\text { Cy5-A10 DNA biotin) }\end{array}$ & $\begin{array}{l}\text { /5Cy5/TCA ACA TCA GTC TGA TAA GCT A- } \\
\text { poly(A) })_{10} / 3 \text { biotin/ }\end{array}$ \\
\hline miR-21 probe DNA (A20 DNA) & $\begin{array}{l}\text { TCA ACA TCA GTC TGA TAA GCT A- } \\
\text { poly(A) })_{20}\end{array}$ \\
\hline Synthetic $\mathrm{T}_{\mathrm{c}}\left(\mathrm{T}_{\mathrm{c}, \mathrm{syn}}, 10 \mathrm{nt}\right)$ & TCA ACA TCA G \\
\hline Synthetic $\mathrm{T}_{\mathrm{c}}\left(\mathrm{T}_{\mathrm{c}, \mathrm{syn}}, 9 \mathrm{nt}\right)$ & TCA ACA TCA \\
\hline Linear template DNA & $\begin{array}{l}\text { /5Phos/GGT TAA TCG CTG AAT GAC GAC } \\
\text { TGA TGT TGA AAA AAA AA TGA CTG TAC } \\
\text { ATG GGT GTA ACC T }\end{array}$ \\
\hline Primer & AGC GAT TAA CCA GGT TAC ACC C \\
\hline DNAzyme substrate & $\begin{array}{l}\text { /5Cy5/TGA CTG TTrA GGA ATG AC/3Iowa } \\
\text { Black® RQ/ }\end{array}$ \\
\hline hsa-miR-21-5p (miR-21) & UAG CUU AUC AGA CUG AUG UUG A \\
\hline miR-21 with 1 mismatch (miR-21 1m (1)) & UAG CUC AUC AGA CUG AUG UUG A \\
\hline miR-21 with 1 mismatch (miR-21 1m (2)) & UAG CUU AUC AGA CUG ACG UUG A \\
\hline hsa-miR-34a-5p (miR-34a) & UGG CAG UGU CUU AGC UGG UUG U \\
\hline hsa-miR-155-5p (miR-155) & UUA AUG CUA AUC GUG AUA GGG GU \\
\hline hsa-miR-10b-5p (miR-10b) & UAC CCU GUA GAA CCG AAU UUG UG \\
\hline hsa-let-7a-5p (let-7a) & UGA GGU AGU AGG UUG UAU AGU U \\
\hline
\end{tabular}

Letters with bold and italics indicate the mismatched base in miR-21. Bold letter ' $r A$ ' indicates ribonucleotide. 


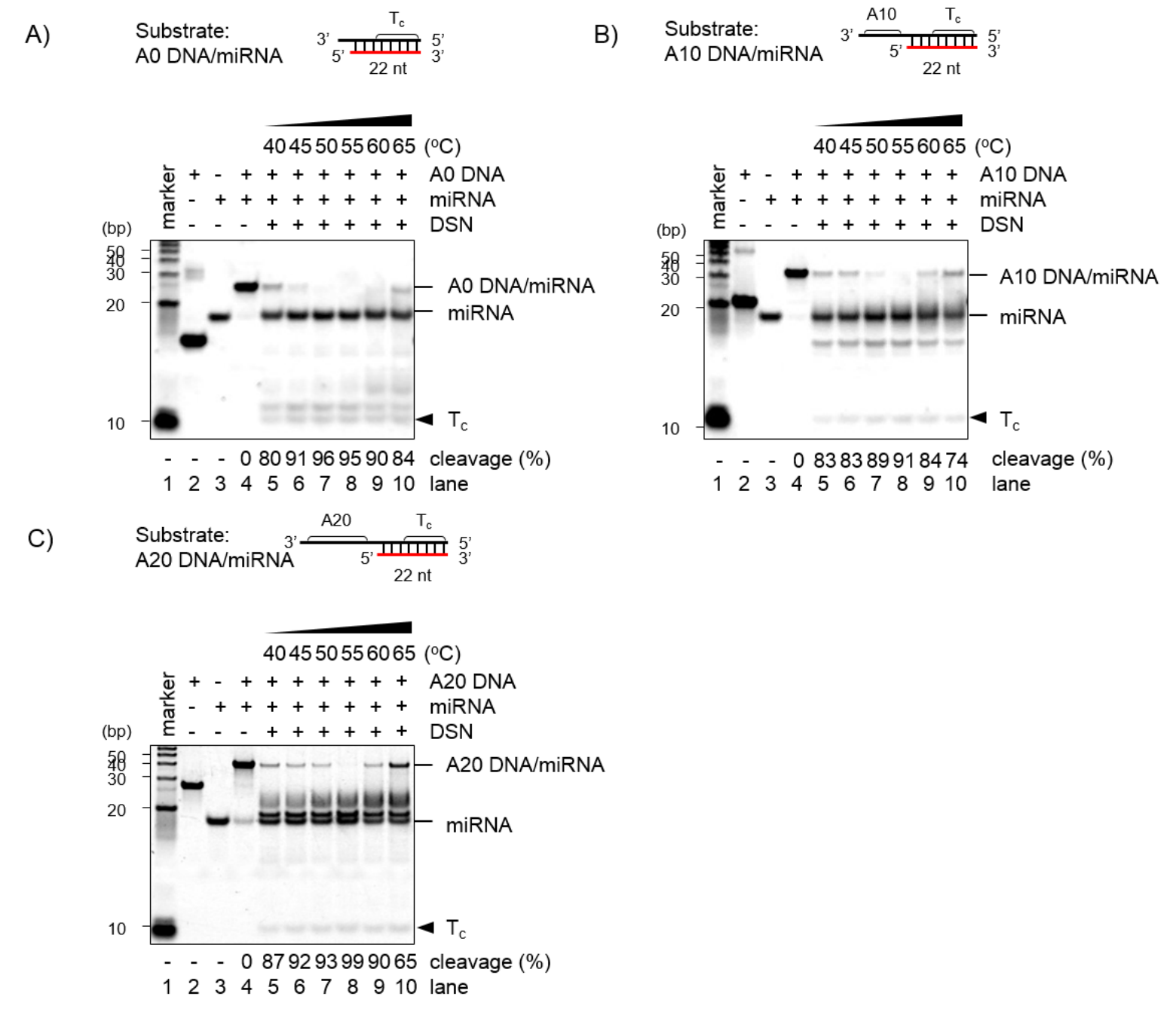

Figure S1. Temperature-dependent catalytic activity of DSN. 15\% native PAGE analysis of A) A0 DNA/miRNA, B) A10 DNA/miRNA, and C) A20 DNA/miRNA duplexes incubated with DSN at

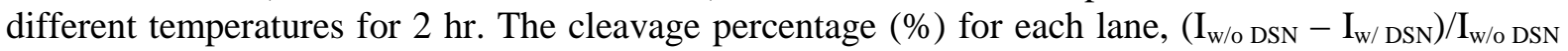
where $I_{\mathrm{w} / \mathrm{o}}$ DSN and $\mathrm{I}_{\mathrm{w} / \mathrm{DSN}}$ are the band intensity of DNA/miRNA without and with DSN respectively, is shown at the bottom. 


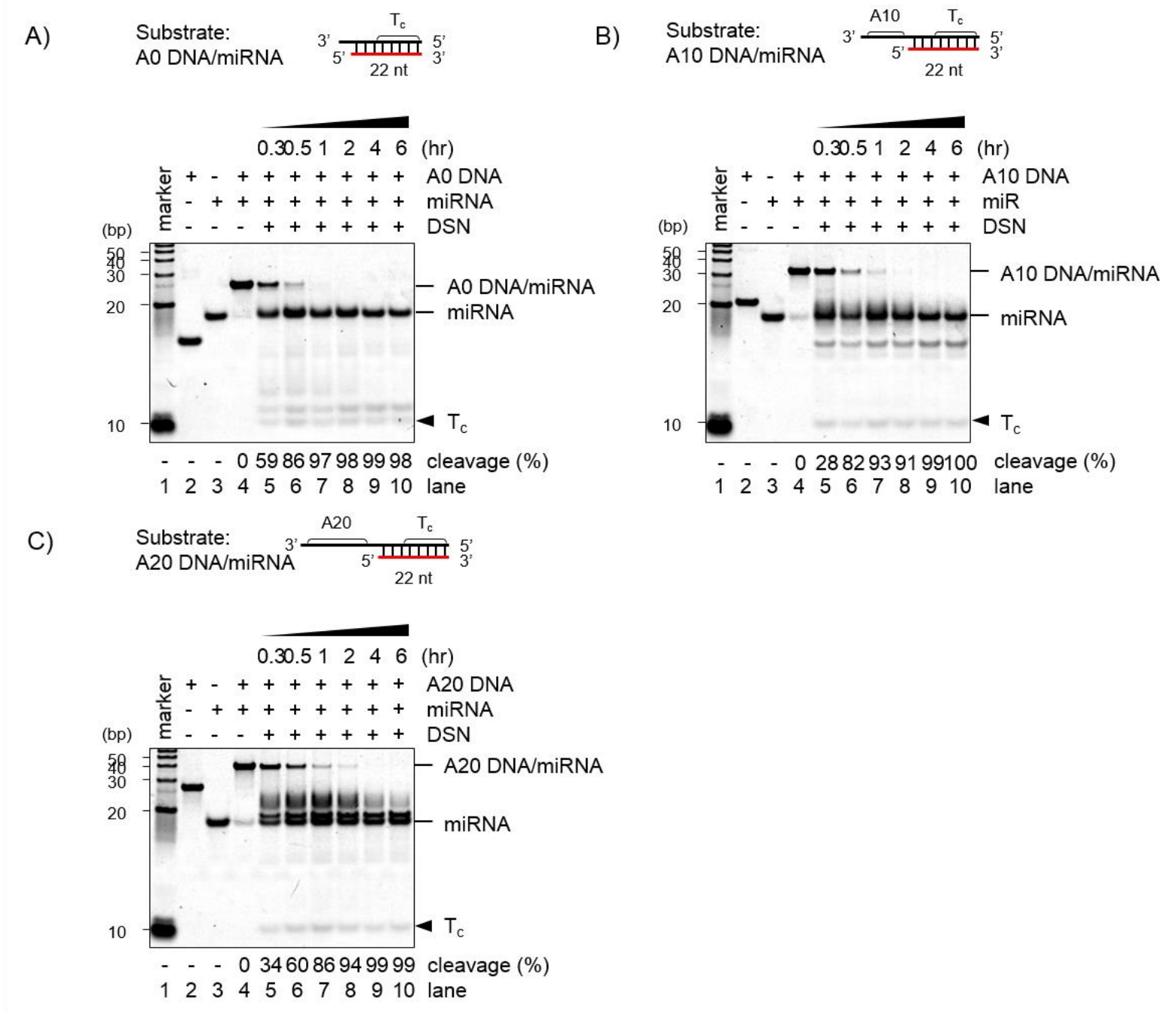

Figure S2. Time-dependent catalytic activity of DSN. 15\% native PAGE analysis of A) A0 DNA/miRNA, B) A10 DNA/miRNA, and C) A20 DNA/miRNA duplexes incubated at $55{ }^{\circ} \mathrm{C}$ for various incubation time. The cleavage percentage (\%) for each lane, $\left(\mathrm{I}_{\mathrm{w} / \mathrm{o} \text { DSN }}-\mathrm{I}_{\mathrm{w} / \mathrm{DSN}}\right) / \mathrm{I}_{\mathrm{w} / \mathrm{o} \text { DSN }}$ where $\mathrm{I}_{\mathrm{w} / \mathrm{DSN}}$ and $\mathrm{I}_{\mathrm{w} / \text { DSN }}$ are the band intensity of DNA/miRNA without and with DSN respectively, is shown at the bottom. 


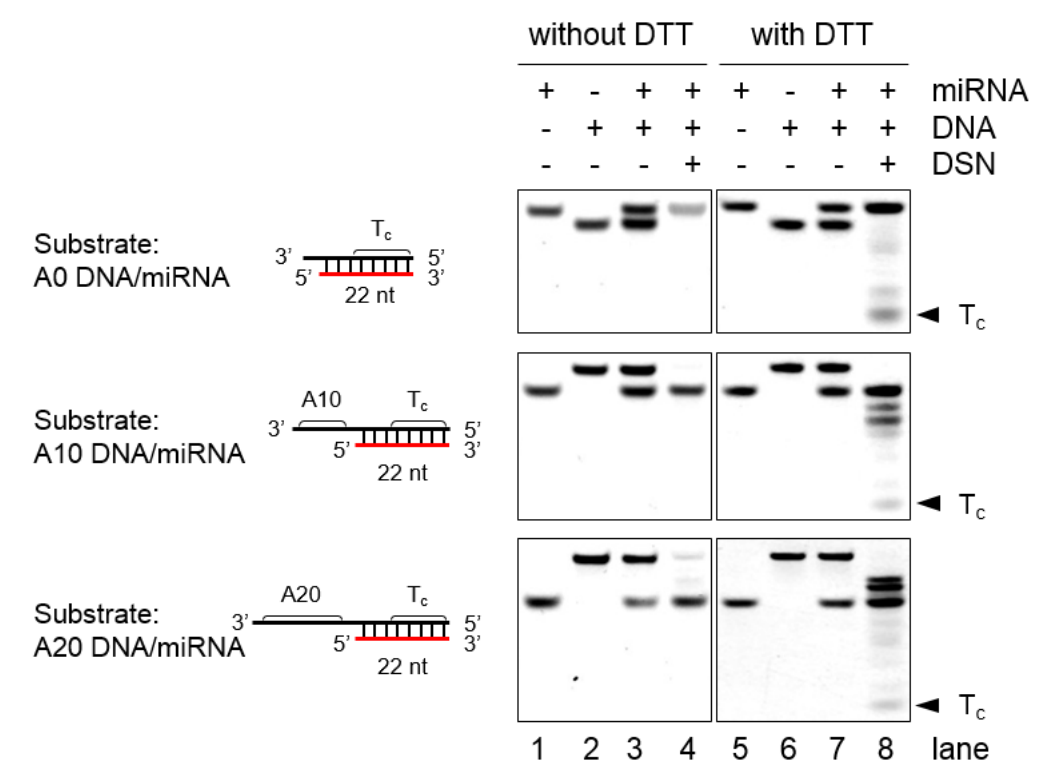

Figure S3. DTT effect on DSN catalytic activity. 20\% denatured PAGE analysis of A0 DNA/miRNA, A10 DNA/miRNA, and A20 DNA/miRNA duplexes incubated with DSN in the reaction buffer without or with DTT.

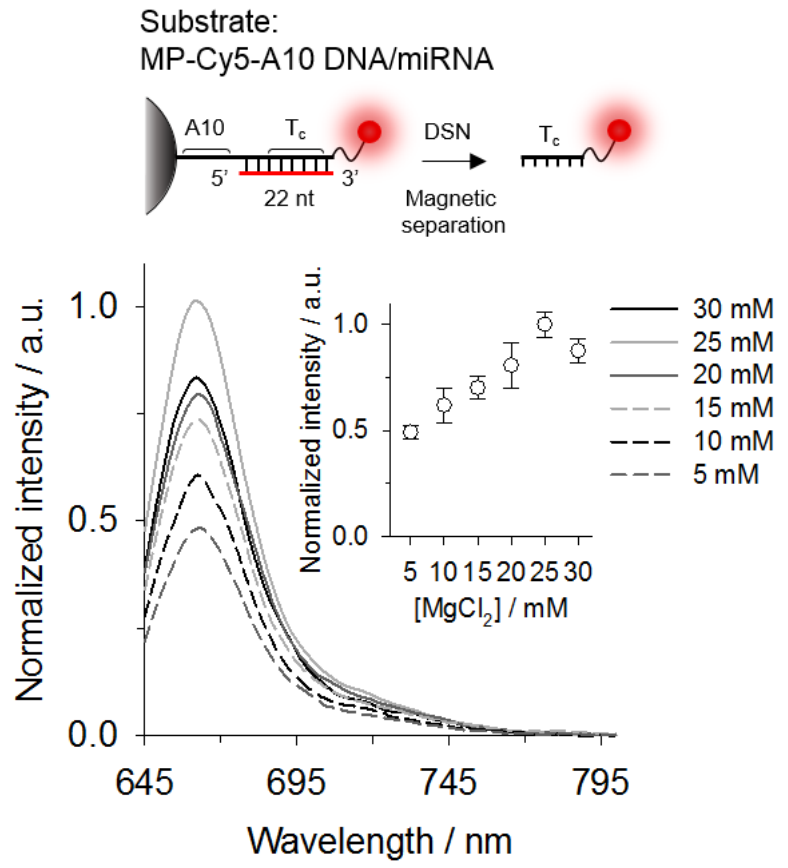

Figure S4. The effect of $\mathrm{MgCl}_{2}$ concentrations on DSN catalytic activity. Fluorescence emission spectra of $\mathrm{T}_{\mathrm{c}}$ solutions obtained from DSN reaction at $55{ }^{\circ} \mathrm{C}$ for $1 \mathrm{hr}$ with different concentrations of $\mathrm{MgCl}_{2}(5,10,15,20,25$, and $30 \mathrm{mM})$ in reaction buffer. [MPs-A10 DNA] $=400 \mathrm{nM},[\mathrm{miRNA}]=10$ $\mathrm{nM}$. Inset: fluorescence changes $\left(\mathrm{F}-\mathrm{F}_{0}, \mathrm{~F}\right.$ and $\mathrm{F}_{0}$ are fluorescence intensity of $\mathrm{T}_{\mathrm{c}}$ solutions in the presence and absence of miRNA, respectively) at $\lambda=663 \mathrm{~nm}$ as a function of $\mathrm{MgCl}_{2}$ concentration. $\mathrm{N}=4$, standard deviation shown in the error bar. 
Substrate:

MP-Cy5-A10 DNA/miRNA

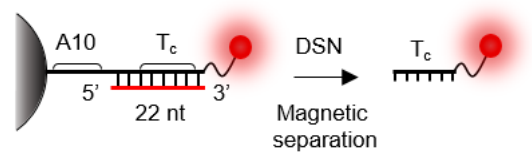

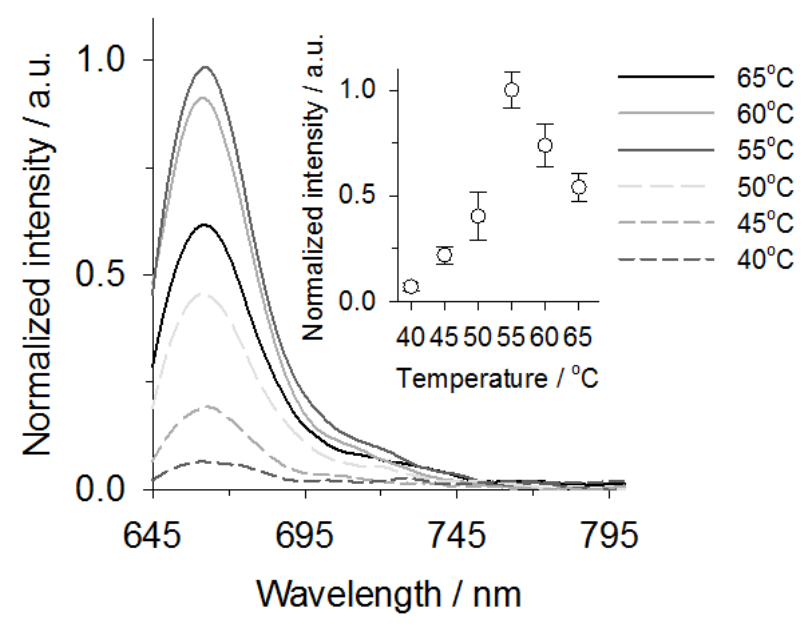

Figure S5. The effect of reaction temperatures on DSN catalytic activity. Fluorescence emission spectra of $\mathrm{T}_{\mathrm{c}}$ solutions obtained from DSN reaction for $1 \mathrm{hr}$ with various incubation temperatures (40, $45,50,55,60$, and $\left.65{ }^{\circ} \mathrm{C}\right) .\left[\mathrm{MgCl}_{2}\right]=25 \mathrm{mM}$, [MPs-A10 DNA] $=400 \mathrm{nM}$, [miRNA] $=10 \mathrm{nM}$. Inset: fluorescence changes at $\lambda=663 \mathrm{~nm}$ as a function of reaction temperature. $\mathrm{N}=4$, standard deviation shown in the error bar.
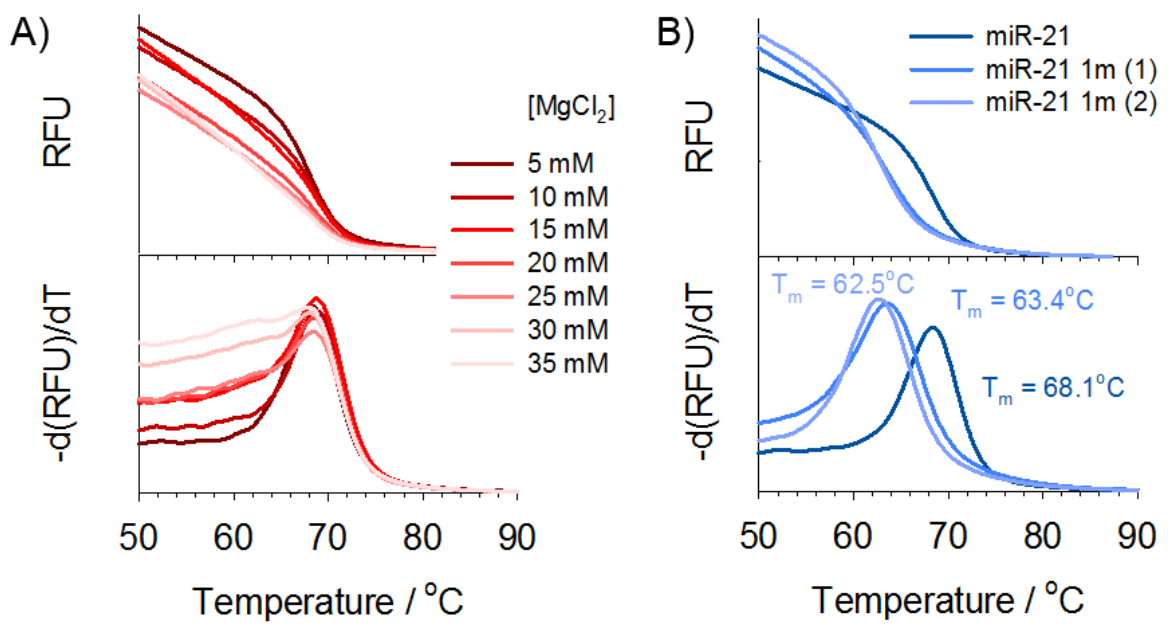

Figure S6. Melt curve analysis of A) DNA/miRNA duplexes in DSN reaction buffer containing various concentrations of $\mathrm{MgCl}_{2}$ and b) perfectly matched or 1 nt-mismatched DNA/miRNA duplexes in DSN reaction buffer containing $5 \mathrm{mM} \mathrm{MgCl}_{2}$. Melt curves were generated by measuring the dissociation of SYBR green I dye from duplexes as a function of temperature (upper). Their derivative curves (lower) are used to assess the melting temperature $\left(\mathrm{T}_{\mathrm{m}}\right)$. 

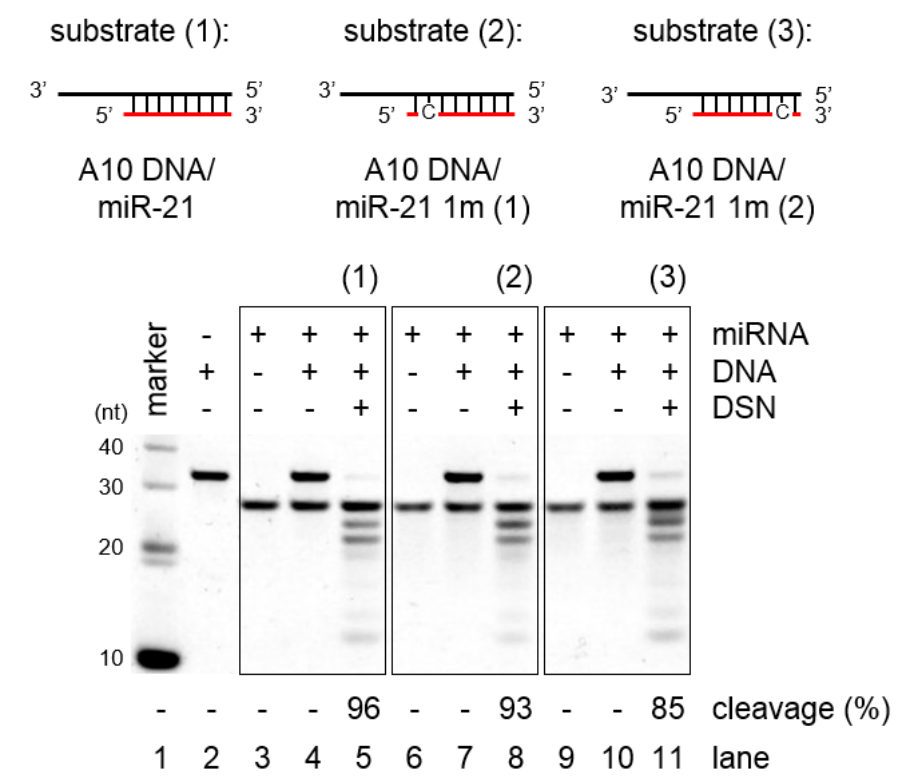

Figure S7. DSN catalytic activity on $1 \mathrm{nt}$ mismatched DNA in DNA/miRNA heteroduplexes. Lane 1: 10 bp DNA marker, lane 2: A10 DNA, lane 3: miR-21, lane 4: DNA/miR-21 duplexes, lane 5: DSNtreated DNA/miR-21 duplexes, lane 6: miR-21 1m (1), lane 7: DNA/miR-21 1m (1) duplexes, lane 8: DSN-treated DNA/miR-21 1m (1), lane 9: miR-21 1m (2), lane 10: DNA/miR-21 1m (2) duplexes, lane 11: DSN-treated DNA-miR21 1m (2) duplexes. The cleavage percentage $(\%)$ for each lane, $\left(\mathrm{I}_{\mathrm{w} / \mathrm{o}}\right.$

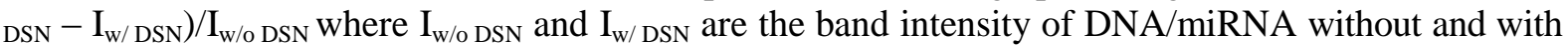
DSN, respectively, is shown at the bottom.
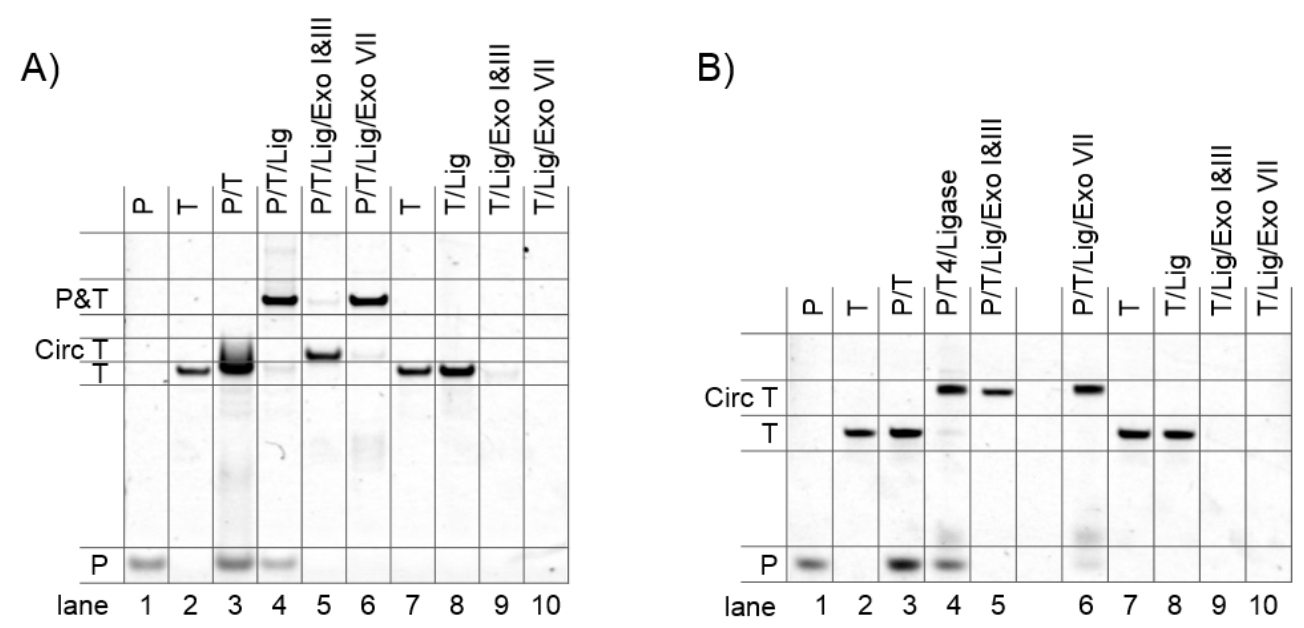

Figure S8. PAGE analysis showing circularization of template DNA. A) $15 \%$ native and B) $15 \%$ denatured polyacrylamide gel images stained with SYBR gold. Lane 1: primer $(\mathrm{P})$, lane 2: template $(\mathrm{T})$, lane 3: hybridization of template with a primer $(\mathrm{P} / \mathrm{T})$, lane 4: ligated template $(\mathrm{P} / \mathrm{T} / \mathrm{Lig})$, lane 5: Exo I- and III-treated circularized template (P/T/Lig/Exo I\&III), lane 6: Exo VII-treated circularized template (P/T/Lig/Exo VII), lane 7: template (T), lane 8: ligated template without a primer (T/Lig), lane 9: Exo I- and III-treated circularized template without a primer (T/Lig/Exo I\&III), lane 10: Exo VII-treated circularized template without a primer (T/Lig/Exo VII). 


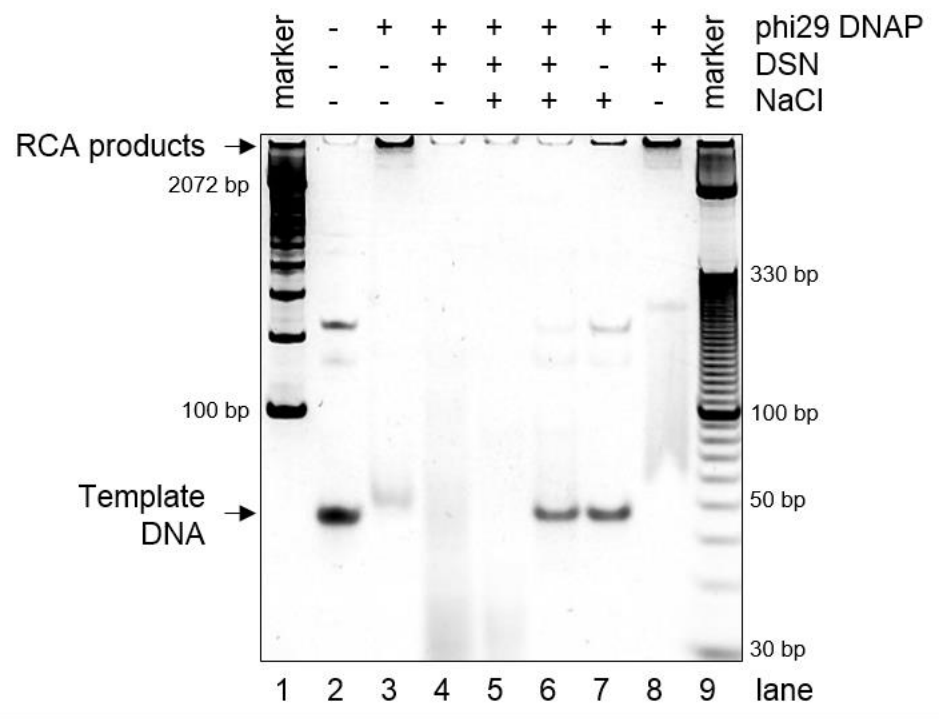

Figure S9. 8\% native PAGE analysis of the RCA products in the presence of DSN. Lane 1: 100 bp DNA marker, lane 2: template DNA, lane 3: RCA with phi29 DNAP, lane 4: RCA with phi29 DNAP and DSN, lane 5 and 6: RCA with phi29 DNAP and DSN in the reaction buffer containing $0.1 \mathrm{M}$ and $0.2 \mathrm{M} \mathrm{NaCl}$, lane 7: RCA with phi29 DNAP in the reaction buffer containing $0.2 \mathrm{M} \mathrm{NaCl}$, lane 8: RCA with phi29 DNAP and inactivated DSN, lane 9: 10 bp DNA marker.
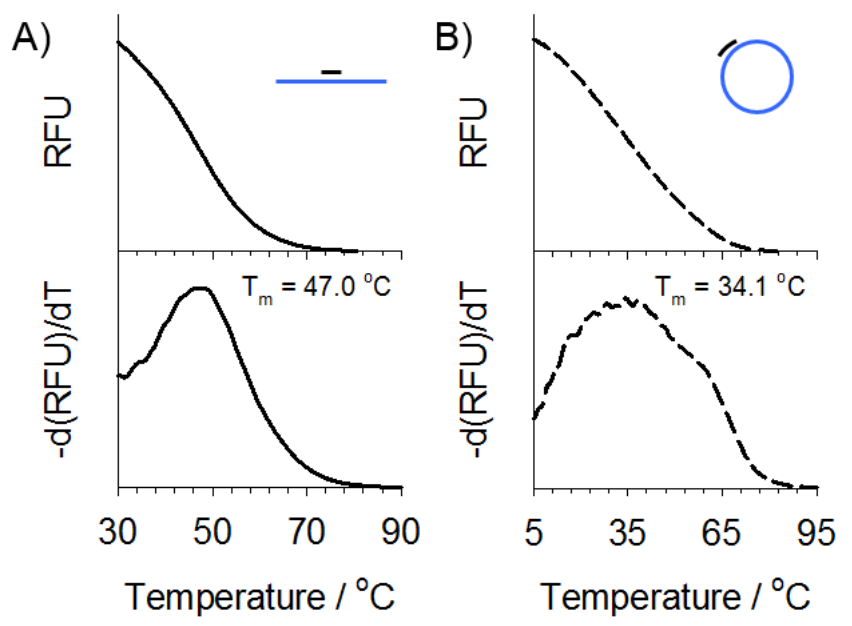

Figure S10. Melt curve analysis of $\mathrm{T}_{\mathrm{c}}$ hybridization with a) linear and $\mathrm{b}$ ) circular template DNA in RCA reaction buffer. Melt curves were generated by measuring the dissociation of SYBR green I dye from duplexes as a function of temperature (upper). Their derivative curves (lower) are used to assess the melting temperature $\left(\mathrm{T}_{\mathrm{m}}\right)$. 


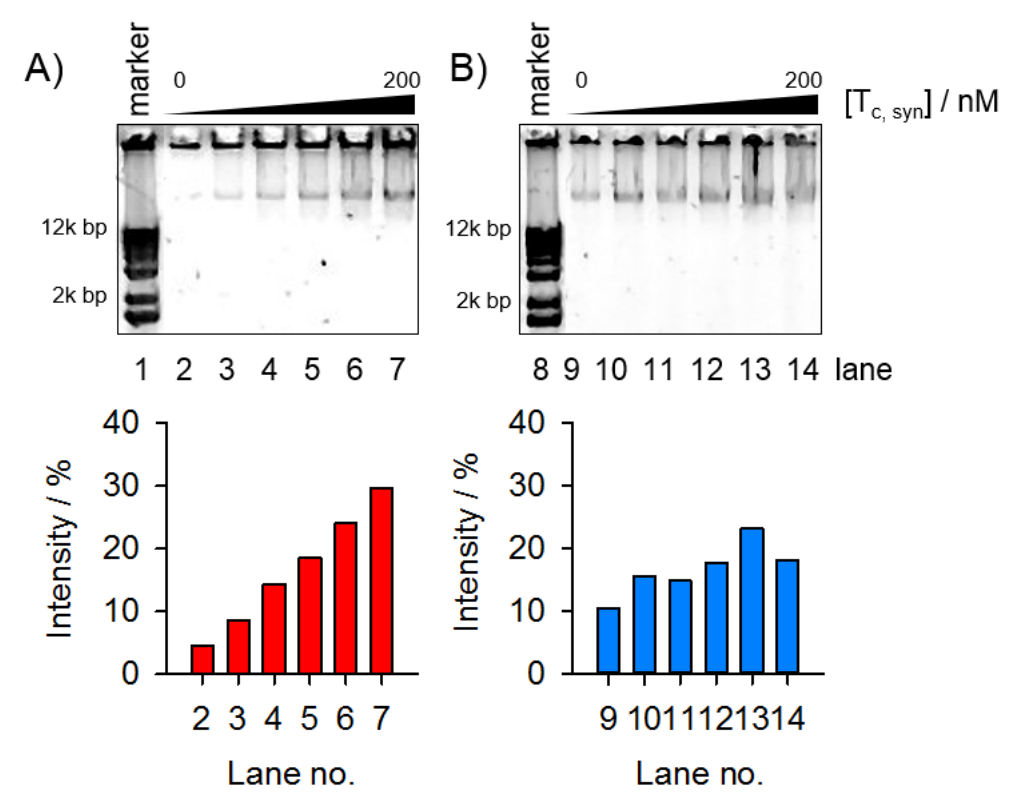

Figure S11. RCA at different incubation temperatures. 1\% agarose gel images and band intensities of the RCA products performed using different concentrations of synthetic $T_{c}\left(T_{c}\right.$, syn $)$ ranging from 0 to $200 \mathrm{nM}$ at A) $15{ }^{\circ} \mathrm{C}$ and B) $30{ }^{\circ} \mathrm{C}$, respectively. Lane 1 and 9: $1 \mathrm{~kb}$ plus DNA marker, lane 2 and 9: 0 $\mathrm{nM}$, lane 3 and 10: $20 \mathrm{nM}$, lane 4 and 11: $40 \mathrm{nM}$, lane 5 and 12: $80 \mathrm{nM}$, lane 6 and 13: $160 \mathrm{nM}$, lane 7 and 14: $200 \mathrm{nM}$.
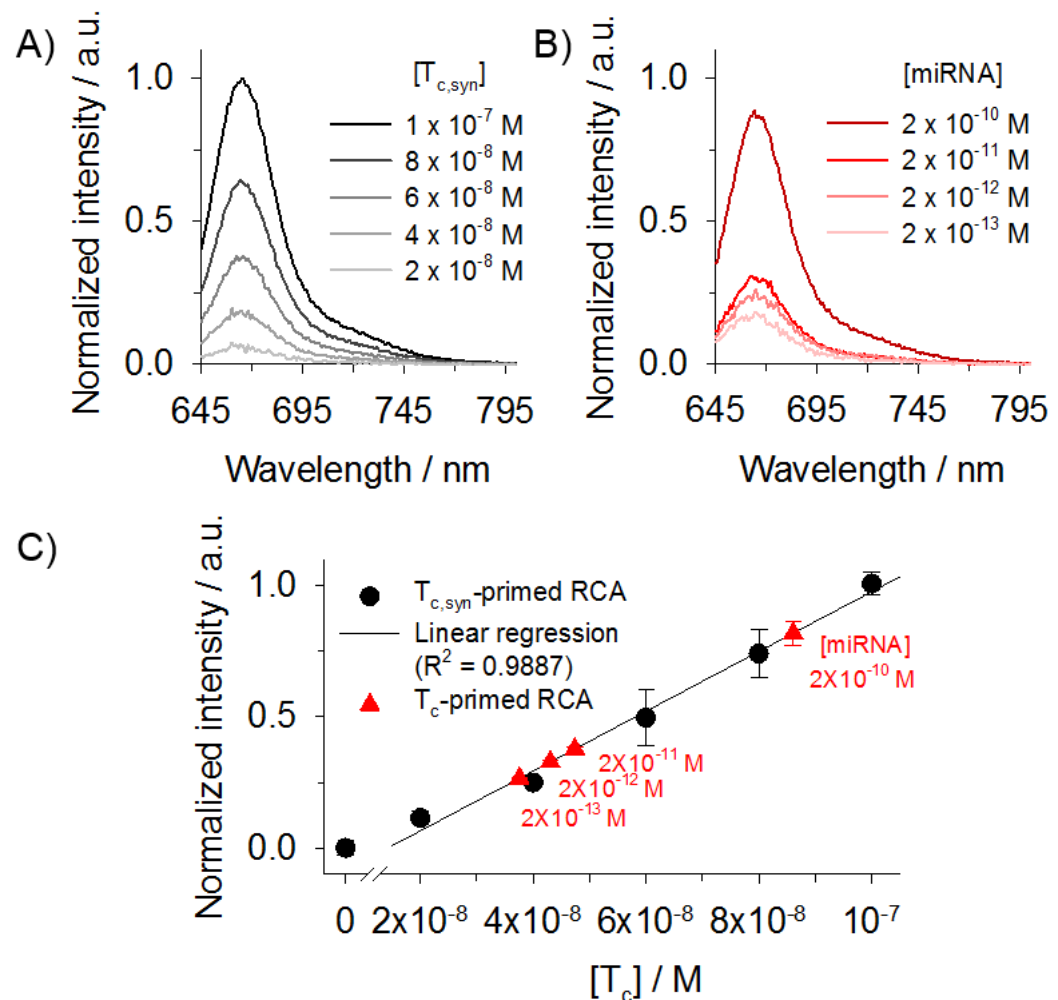

Figure S12. Comparison of detection limit between $\mathrm{T}_{\mathrm{c}^{-}}$and $\mathrm{T}_{\mathrm{c}, \mathrm{syn}}$-mediated RCA. Fluorescence emission spectra of RCA products with a) $\mathrm{T}_{\mathrm{c}, \mathrm{syn}}(20 \mathrm{nM}, 40 \mathrm{nM}, 60 \mathrm{nM}, 80 \mathrm{nM}$, and $100 \mathrm{nM})$ and b) amplified $T_{c}$ obtained from DSN reaction with miRNA (200 fM, $2 \mathrm{pM}, 20 \mathrm{pM}$, and $200 \mathrm{pM}$ ). c) Fluorescence changes $\left(\mathrm{F}-\mathrm{F}_{0}\right.$ at $\left.\lambda=665 \mathrm{~nm}\right)$ of RCA products with various concentrations of $\mathrm{T}_{\mathrm{c}, \mathrm{syn}}$ (black circles). This curve was fit using linear least squares regression analysis and used to quantify the concentration of released $\mathrm{T}_{\mathrm{c}}$ from DSN-treated MPs-A10 DNA in the presence of target miRNA (red triangles). $\mathrm{N}=3$, standard deviation shown in the error bar. 


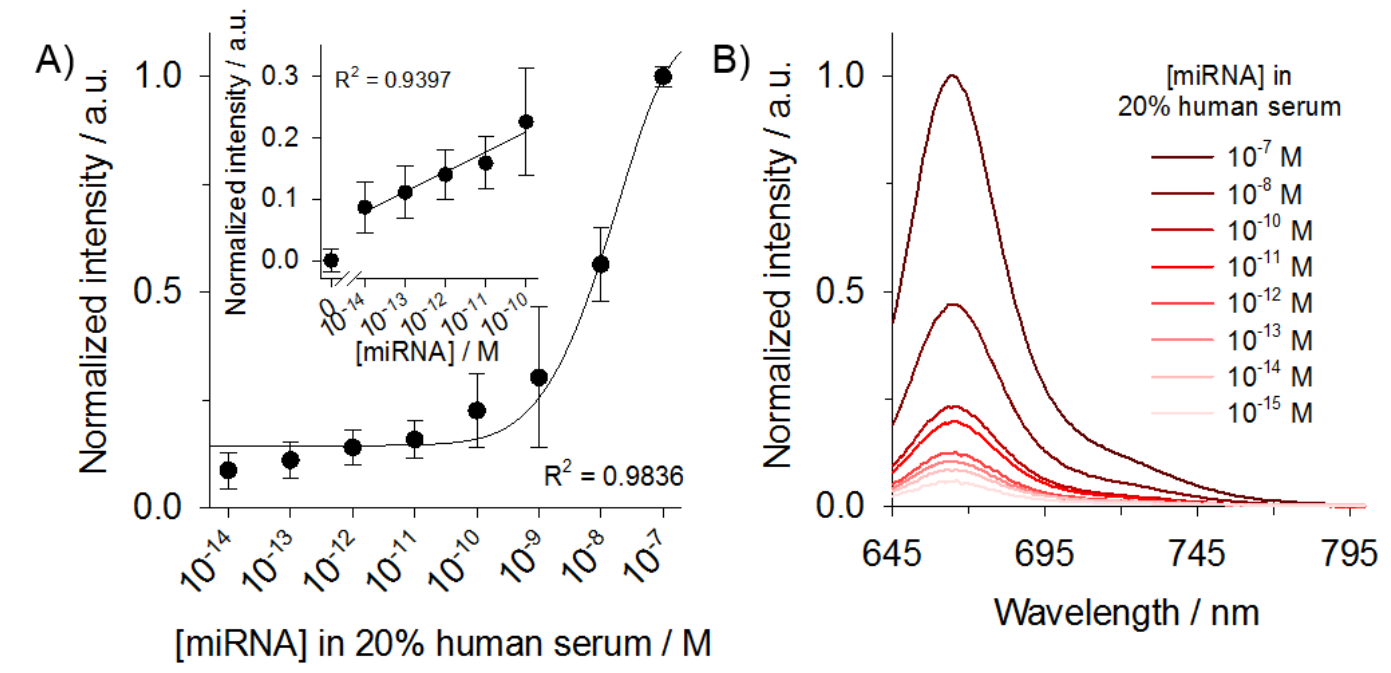

Figure S13. Detection of target miRNA (miR-21) spiked in $20 \%$ human serum with amplified $\mathrm{T}_{\mathrm{c}^{-}}$ primed RCA assay. a) Target dose-responsive fluorescence changes at $\lambda=665 \mathrm{~nm}$ and b) emission spectra of each sample at $\lambda_{\mathrm{ex}}=630 \mathrm{~nm}$. [MPs-A10 DNA] $=600 \mathrm{nM},[\mathrm{DSN}]=0.005 \mathrm{U} / \mu \mathrm{L}, \mathrm{DSN}$ reaction was carried out at $55^{\circ} \mathrm{C}$ for $2 \mathrm{hr}$. [circular template DNA] $=167 \mathrm{nM}$, [phi29 DNAP] $=0.083$ $\mathrm{U} / \mu \mathrm{L}$. RCA was performed at $15^{\circ} \mathrm{C}$ for $3 \mathrm{hr}$. [DNAzyme substrate] $=1 \mu \mathrm{M}$. $\mathrm{N}=3$, standard deviation shown in the error bar.

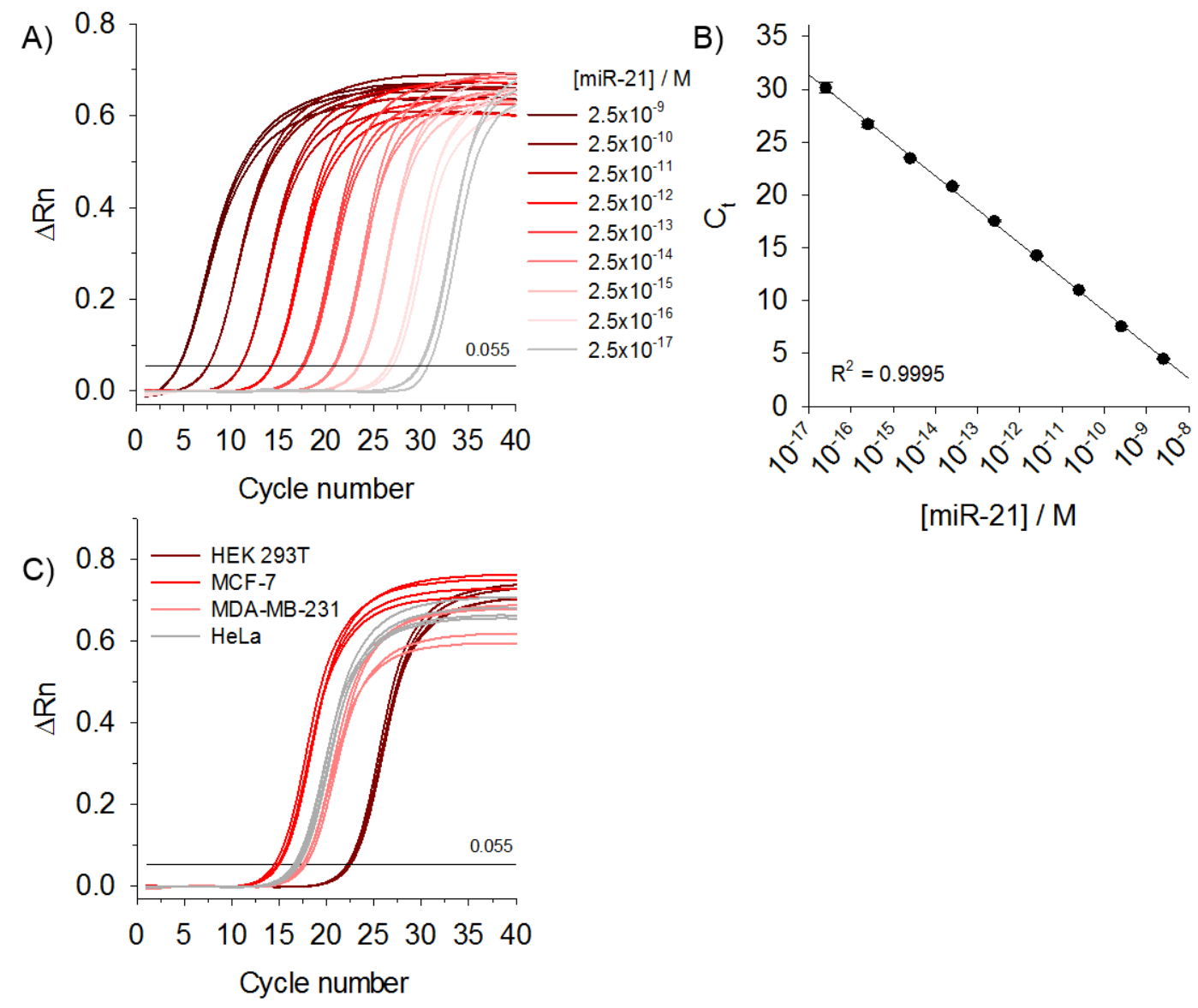

Figure S14. Quantification of miR-21 with qRT-PCR. a) Amplification plots and b) a standard curve from PCR for 10-fold dilution series ranging from $2.5 \times 10^{-17}$ to $2.5 \times 10^{-9} \mathrm{M}$ of synthetic miR-21. $\mathrm{N}=3$ technical replicates, standard deviation shown in the error bar. c) Quantification of miR-21 in total RNA extracted from various cell lines by qRT-PCR. $\mathrm{N}=4$ biological replicates. 


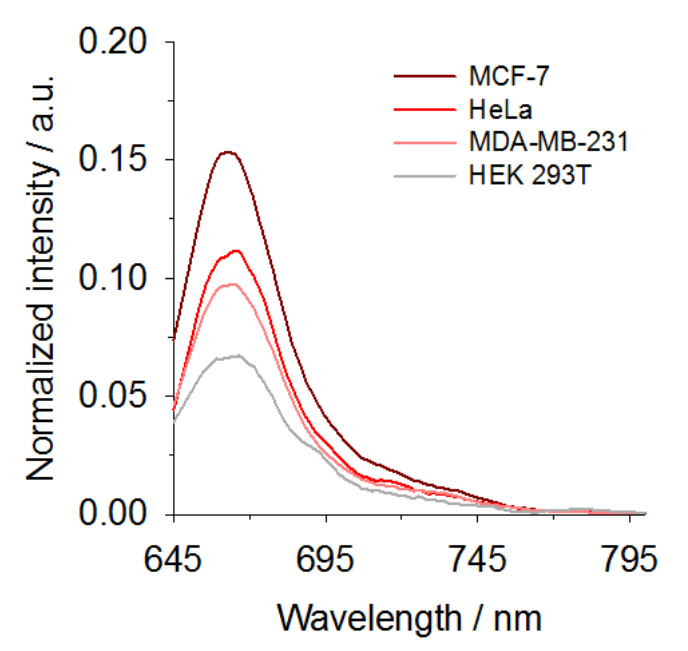

Figure S15. Quantification of miR-21 in total RNA isolated from various cell lines by $\mathrm{T}_{\mathrm{c}}$-primed RCA. Normalized emission spectra of the final RCA products with $2 \mu \mathrm{L}$ of total RNA extracted from cells at $\lambda_{\mathrm{ex}}=630 \mathrm{~nm}$. [MPs-A10 DNA] $=600 \mathrm{nM},[\mathrm{DSN}]=0.005 \mathrm{U} / \mu \mathrm{L}$, [circular template DNA] $=$ $167 \mathrm{nM},[\mathrm{phi} 29 \mathrm{DNAP}]=0.083 \mathrm{U} / \mu \mathrm{L},[$ DNAzyme substrate $]=1 \mathrm{mM}$. 